\title{
THE EFFECT OF LEARNING CYCLE 5E ON GLOBAL WARMING THEME TO ENCOURAGE STUDENTS' SCIENTIFIC PROCESS SKILLS
}

\author{
Nurma Yuniarsih $^{1}$, Yuni Arfiani ${ }^{2}$, Muriani Nur Hayati ${ }^{3}$ \\ ${ }^{1,2,3}$ Pendidikan IPA, FKIP, Universitas Pancasakti Tegal \\ Tegal, 42122, Indonesia \\ nurma_yuniarsih@upstegal.ac.id \\ DOI: https://doi.org/1921107/jps.v7i2.6697
}

\begin{abstract}
This study aimed to determine the effect of the Learning Cycle 5E model on junior high school students' science process skills. This study used the Quasi-Experimental Design study with Nonequivalent control group design. The instrument used a science process skills test. The research sample is students in class VII semester II of Junior High Scool 8 Pekalongan, which purposive random sampling technique. The data were collected by essay tests of science process skills, observation sheets, and documents. Analytical data were used instrument analysis, pretest, and posttest of science process skills, etc. Based on the value of n-gain from Learning Cycle $5 E$ class were obtained 66.33 with moderate criteria, so the Learning Cycle $5 E$ model is moderate in science process skills. The students' responses towards the Learning Cycle $5 E$ model were positive, 14 of the 15 statement items included in the excellent category. It indicates that the learning cycle $5 E$ can encourage students' science process skills.
\end{abstract}

Keywords: Effectiveness, Learning Cycle 5E, science process skill, global warming. 


\section{Pendahuluan}

The learning process requires active, dynamic, and fun learning strategies and patterns to stimulate students' learning creativity. The learning process that uses various senses in each student's body is an acceptable form of learning. Learning with this process will produce ideal student competencies. If knowledge is carried out well and improves student learning outcomes, the quality of education will increase. One of the lessons improved in its implementation in junior high schools is science learning (Surna \& Pandeirot, 2014).

Science is a subject that invites students to be directly involved and discover their knowledge of existing natural phenomena. Science broadly has three components: a product, a process, and a scientific attitude. The science learning process in the 2013 curriculum emphasizes applying a scientific approach in each learning process (Permendikbud, 2013). Science subjects are said to be difficult because science subjects only discuss the theories and formulas they learn. According to Nurlaela et al. (2016), science learning provides direct experience and helps students further strengthen students' memory.

Science learning requires strategies that can make students understand the concept through active learning to create meaningfully and understand the concept well. It is necessary to apply learning that can provide space or opportunities for students to play an active role and develop an understanding of science learning activities, for example, using an appropriate learning model. One learning model that can overcome these problems is the Learning Cycle 5E model. The Learning Cycle 5E model is a series of activity stages organized to master the competencies that must be achieved by taking an active role (Kulsum \& Hindarto, 2011). The advantages of the Learning Cycle 5E model are increasing learning motivation because learners are actively involved in the learning process. Students can receive experiences from others, develop successful individual potential, and optimize themselves against changes. Learning Cycle 5E learning models can make students more active in finding concepts through experiments. Students do not feel bored with monotonous learning so that science process skills can be achieved. Science learning emphasizes providing direct learning experiences by applying process skills.

One of the materials in science learning combined with the Learning Cycle 5E model is global warming material. This material refers to BC 3.10, describing the causes of global warming and its impact on ecosystems, and $\mathrm{BC} 4.13$, presenting data and information on global warming to provide an overview of problem-solving (Kemendikbud, 2013).

Teachers have never implemented the Learning Cycle 5E model. It is also related to the type of material delivered by the teacher, which will impact science process skills. Science learning activities that have been carried out have not led to improved students' science process skills (Hayati et al. 2014). Science process skills provide opportunities for students to be able to find facts, build concepts through activities or experiences such as scientists. (Yusuf \& Wulan, 2015). Science process skills are classified into 10, including: observing, grouping or classifying, interpreting, predicting, asking questions, formulating hypotheses, planning experiments, using tools and materials, applying concepts, and communicating (Yusuf \& Wulan, 2015).

The ability of science process skills cannot develop properly because these students have difficulty connecting the things to be learned with problems in everyday life. It is because schools and teachers do not facilitate students to carry out learning activities by applying science process skills (Gusdiantini et al. 2017). The importance of knowing: how effective the Learning Cycle $5 \mathrm{E}$ is as an effort to encourage students to develop science process skills?

\section{Research Method}

The research design used was quasiexperimental in a nonequivalent control group design (pretest and posttest). This design is used to compare students' progress after learning and before learning between the Learning Cycle $5 \mathrm{E}$ class (experiment) and the conventional class (control). This research was conducted at SMP N 8 Pekalongan with the research subjects of class VII students 2018/2019. The sampling technique used a purposive random sampling technique to obtain classes VII D, VII E, and VII F. Class VII D students as the test class, class VII E as the Learning Cycle 5E class, and class VII F as the conventional class. The research method used includes documentation, test scientific process skills description, observation, and questionnaires. The instruments in this study included 1) treatment instruments, namely syllabus, lesson plan, and student worksheets, and 2) measurement instruments, namely learning implementation 
observation sheets, science process skills sheets, science process skills description tests. The question of science process skills, which is given in the form of a non-objective test, demands answers based on each student (Depdiknas, 2008). Observations were made during the learning process for two meetings. The tests used in this study were 10 of the 15 questions tested for validation by experts. The validation test includes a content validation test and a construct validation test. The instrument was previously tested on class VII D students (trial class) on 15 questions containing each indicator of science process skills.

Initial ability data and students' science process skill scores in the control class and experimental class were seen for their normality and homogeneity as a prerequisite test for conducting hypothesis testing on the value of science process skills. Interpretation of normality and homogeneity is carried out based on the significance value. The increase in the value of science process skills in the 5E Learning Cycle class and the conventional class can be seen from the gain index value obtained from the pretest and posttest. The effectiveness category uses data interpretation from the result of students' tests and responses with table 1 .

Table 1. The Category of Effectiveness

\begin{tabular}{cc}
\hline$\%$ & Information \\
\hline$<40$ & Not Effective \\
$40-55$ & Less Effective \\
$56-75$ & Moderate Effective \\
$<76$ & Effective \\
\hline
\end{tabular}

\section{Result and Discussion}

description Validity Test

The validity test uses the logical validation test, including the content validation test and the construct validation test. Test the validation of questions using the SPSS 17.0 program. The validity test includes the validity of the items, the questions' reliability, the difficulty index, and the distinguishing power. Test the validity of the questions obtained by testing the students. The analysis is then interpreted based on the reference criteria for the validity of the items. The reliability test aims to determine the level of reliability of the test using Alpha Cronbach. Sudjana (2011) states that the reliability test is that whenever the assessment tool gives the same realistic results. The difficulty index is calculated by comparing the students who answered the questions correctly against the total number of subjects, then analyzed using the anatest and interpreted based on the level of difficulty reference criteria. Arifin (2013) states that the difficulty level of the questions is a consideration in determining the proportion of the number of questions in the easy, medium, or difficult categories. The analysis of discriminating power is used to examine the items to determine the questions' ability to distinguish students classified as capable and classified as less competent.

Table 2. The result of Testing The Science Process Skills Instrument

\begin{tabular}{|c|c|c|c|c|c|c|}
\hline No & Criteria of Instrument & Code & Validation & Difficulty Index & $\begin{array}{l}\text { Distinguish } \\
\text { Power }\end{array}$ & Decision \\
\hline 1 & Observe & M1 & High & Easy & Excellent & Accepted \\
\hline 2 & Interpret & M3 & Moderate & Moderate & Excellent & Accepted \\
\hline 3 & Classify & M2 & Low & Moderate & Good & Accepted \\
\hline $\begin{array}{l}4 \\
5\end{array}$ & $\begin{array}{l}\text { Using Tools and Material } \\
\text { Predict }\end{array}$ & $\begin{array}{l}\text { M8 } \\
\text { M4 }\end{array}$ & $\begin{array}{c}\text { Low } \\
\text { Moderate }\end{array}$ & $\begin{array}{l}\text { Moderate } \\
\text { Moderate }\end{array}$ & $\begin{array}{c}\text { Good } \\
\text { Excellent }\end{array}$ & $\begin{array}{l}\text { Accepted } \\
\text { Accepted }\end{array}$ \\
\hline 6 & Asking Question & M5 & High & Moderate & Excellent & Accepted \\
\hline 7 & Formulate a Hypothesis & M6 & Moderate & Moderate & Excellent & Accepted \\
\hline 8 & Implement Concept & M9 & Moderate & Moderate & Excellent & Accepted \\
\hline 9 & Communication & M10 & High & Moderate & Excellent & Accepted \\
\hline 10 & Planning Experiment & M7 & Moderate & Moderate & Excellent & Accepted \\
\hline 11 & Observe & M1 & Very Low & Difficult & Moderate & Rejected \\
\hline 12 & Predict & M4 & Moderate & Moderate & Excellent & Rejected \\
\hline 13 & Interpret & M3 & Very Low & Difficult & Good & Rejected \\
\hline 14 & Implement Concept & M9 & Low & Moderate & Good & Rejected \\
\hline 15 & Formulate a Hypothesis & M6 & Low & Moderate & Good & Rejected \\
\hline
\end{tabular}


Based on Table 2, the pretest and post-test questions were taken ten questions, and each item represented one indicator of science process skills. If there are two questions with high and enough categories in one indicator, then the questions in the high category are taken. It can be interpreted that the ten questions used; there were three questions with high validation criteria, five questions with sufficient validation criteria, and two questions with low validation. The reliability result is 0.707 (table 3), so it can be interpreted that the instrument is said to be reliable. According to Kapla and Saccuazo (1993), a good reliability coefficient to use is in the range of 0.7 .

Table 3. The Result of Reliability Test

\begin{tabular}{lc}
\hline \multicolumn{2}{c}{ Statistic of Reliability } \\
\hline Cronbach's Alpha & Number of Items \\
\hline 0,707 & 15 \\
\hline
\end{tabular}

\section{Science Process Skills}

The data on the science process skills test results consisted of pretest and postest data in the experimental class and the control class. The pretest was carried out before the learning process of global warming material. In contrast, the posttest was carried out after the learning process of global warming material with the Learning Cycle 5E model in the experimental class and the control class's conventional learning model.

Table 4. Description of the pretest value for the Learning 5E Cycle class and the Conventional class

\begin{tabular}{llll}
\hline \multicolumn{1}{c}{ Pretest } & $\begin{array}{c}\text { Number } \\
\text { of } \\
\text { Students }\end{array}$ & Mean & S.D. \\
\hline Experiment Class & 34 & 34.82 & 7.171 \\
Control Class & 34 & 30.50 & 6.200 \\
\hline
\end{tabular}

The data in Table 4 shows that the mean value in the experimental class is 34.84 , while in the control class, the mean value is 30.50 , which means that the two classes did not reach the predetermined minimum completeness value of 75 .

Table 5. Description of the posttest value for the Learning Cycle 5E class and the Conventional class

\begin{tabular}{llll}
\hline \multicolumn{1}{c}{ Postest } & $\begin{array}{c}\text { Number } \\
\text { of } \\
\text { Students }\end{array}$ & Mean & S.D. \\
\hline Experiment Class & 34 & 79.91 & 3.519 \\
Control Class & 34 & 55.29 & 3.119 \\
\hline
\end{tabular}

The data in Table 5 shows that the mean value in the experimental class is 79.91. In the control class, the mean value is 55.29 , which means that only the control class achieves the predetermined minimum completeness value of 75 .

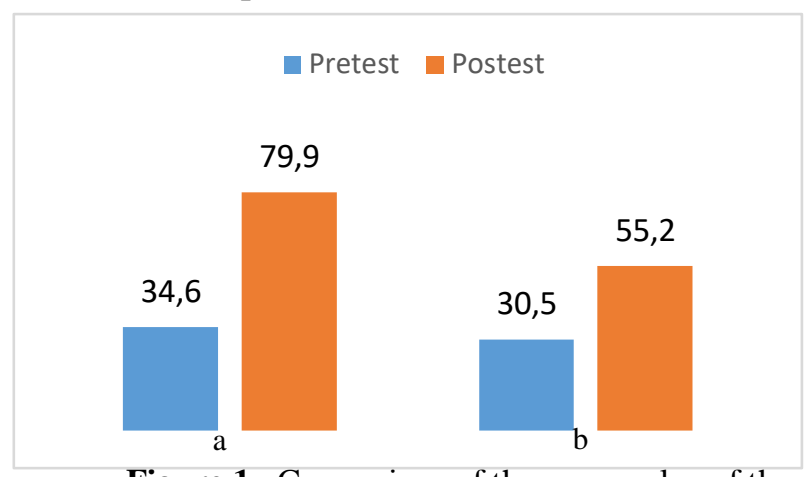

Figure 1. Comparison of the mean value of the pretest and posttest in the Learning Cycle 5E class (a) and the Conventional class (b)

Figure 1 shows the pretest and posttest scores that students in the Learning Cycle $5 \mathrm{E}$ class were 34.5 in the category of having less science process skills indicators. In contrast, the conventional class on the pretest results got an average of 30.5 to have less science process skills after being given treatment in the form of a different learning model in the Learning Cycle 5E class (experiment) using the Learning Cycle 5E model while the conventional class (control). The average posttest result of the Learning Cycle 5E class got the value of each indicator of science process skills, and the mean value was higher by 79.9 with a good category who had science process skills compared to students in the conventional class of 55.9 with a sufficient category to have science process skills. This situation shows that the application of the Learning Cycle 5E model can improve science process skills. Research from Qarareh (2012) states an average increase in the experimental class treated with the Learning Cycle 5E model compared to the control class treated with the traditional model.

Based on the results of Figure 2, the average posttest score of students has increased, seen from each indicator. The indicator that has grown significantly for the two classes is the indicator planning experiments (M7) questions. In this indicator, students are asked to mention the function of the thermometer and stopwatch. Students have mastered the initial ability of these tools. Meanwhile, the indicators using the Learning Cycle 5E class tools and materials were significantly superior to the conventional class. The Learning Cycle 5E class carried out experiments, prepared instruments and materials, and used the tools and materials designed. Students in the Learning Cycle 5E class were superior to indicators using tools and materials compared to the untreated conventional class. 


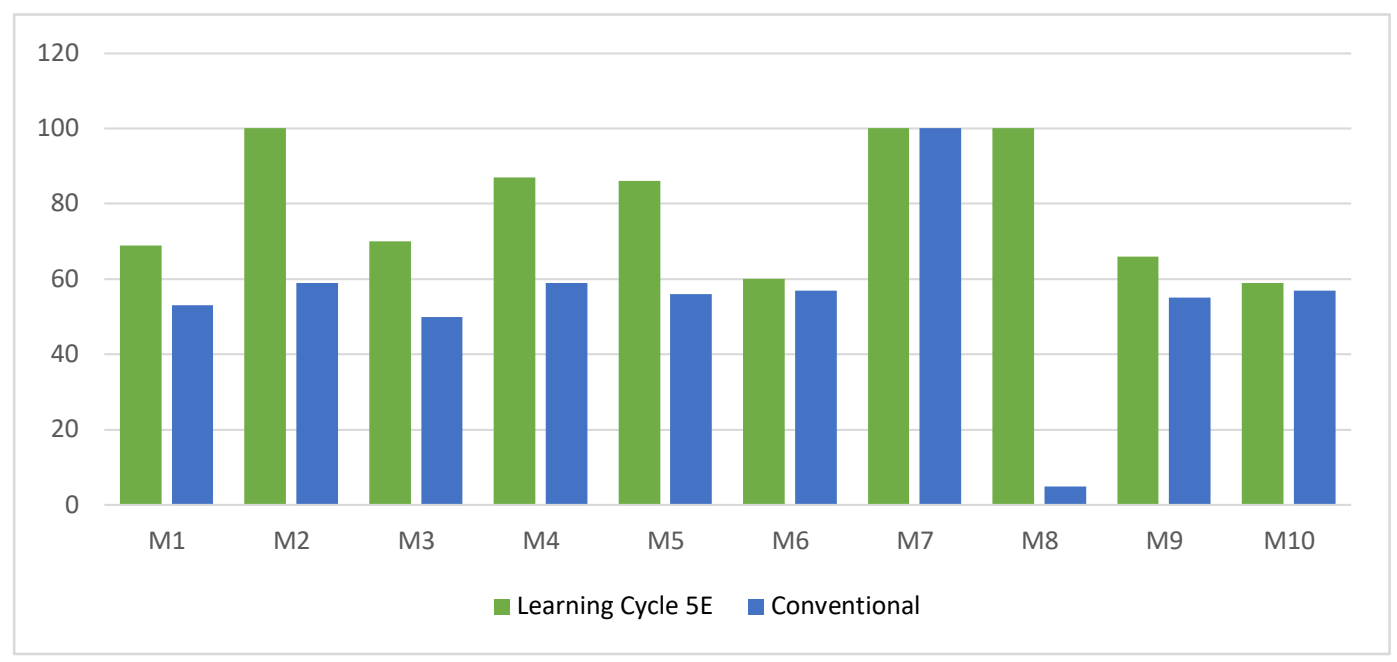

Figure 2.The results of the average score of science process skills in the Learning Cycle 5E class and the conventional class

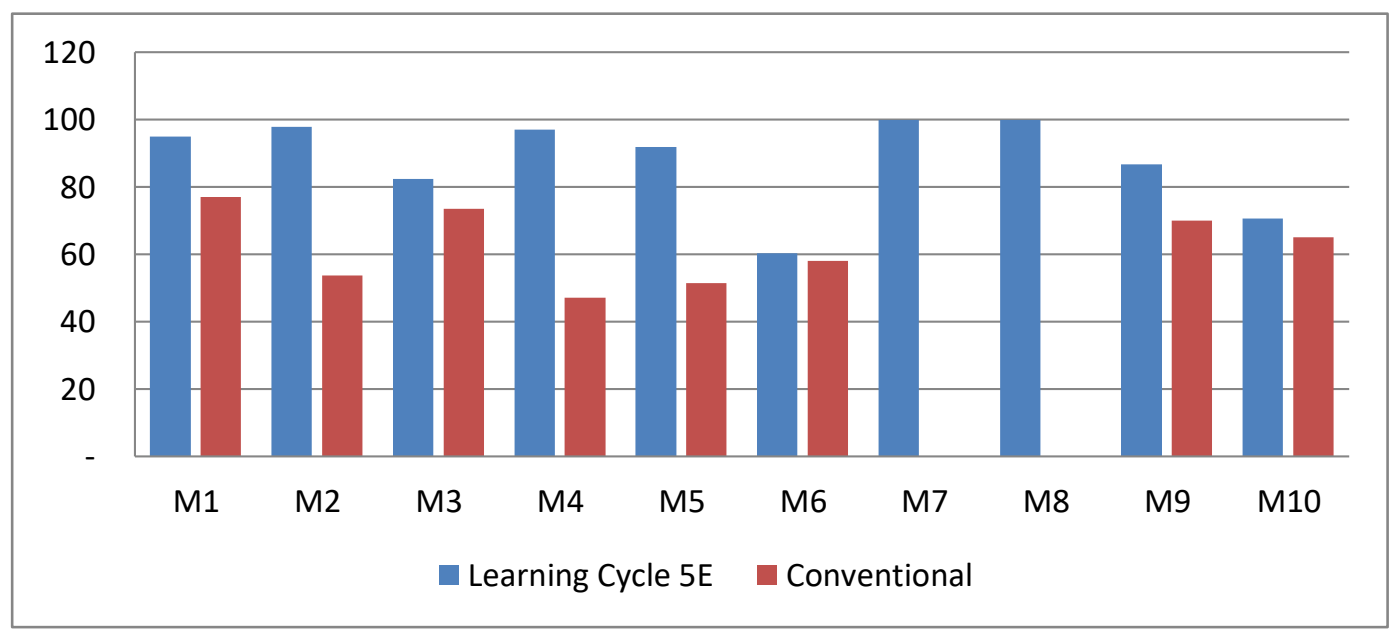

Figure 3. The average results of the Science Process Skills assessment

Figure 3 shows the average for each science process skills indicator in the Learning Cycle 5E class and conventional class. Learning Cycle 5E class, 8 out of 10 indicators of science process skills are in the very good category, including observing (M1), grouping (M2), interpreting (M3), predicting (M4), asking questions (M5), planning experiments (M7), using tools and materials (M8), and applying the concept (M9). Meanwhile, the communication indicator (M10) is in a good category, and the indicator for formulating a hypothesis (M6) is in a sufficient category.

In the conventional class, three indicators are in a good category, including observing, interpreting, and applying the concept. Three indicators are in the sufficient category, including grouping, predicting, asking questions, and formulating hypotheses. Meanwhile, the other three indicators are in the very poor category, including planning experiments, using tools and materials, and communicating. The reason is that there are differences in the learning models used. In the Learning Cycle 5E class, all indicators of science process skills can be used in the learning process, while in conventional classes, not all indicators of science process skills can be used in learning. The results of this study were supported by Usmiatin (2014), which revealed that there were differences in the science process skills of students who were taught by Learning Cycle 5E students and students who learned conventional.

The increase in students' science process skills in the Learning Cycle 5E class and conventional class can be seen from the n-gain value obtained from the pretest and post-test in Table 6 .

Table 6. N-Gains Score

\begin{tabular}{lll}
\hline Class & N-gain & Information \\
\hline Learning Cycle 5E & 66,33 & Moderate \\
Conventional & 35,18 & Less \\
\hline
\end{tabular}


Table 6 shows the gain index value between the Learning Cycle 5E class and the conventional class; there are differences. The Learning Cycle 5E class includes moderate criteria, while the conventional class has less criteria. This is because the indicators of every aspect of science process skills are less specific; not all students can master every aspect of scientific process skills that have been determined. Other research supports from Sibel (2011), Akar (2005) that the Learning Cycle $5 \mathrm{E}$ is an effective way to help students acquire knowledge, understand the content, and apply science concepts and processes to authentic situations. Therefore, the Learning Cycle 5E learning model can create learning that is quite effective compared to learning using conventional models. The effectiveness of the Learning Cycle $5 \mathrm{E}$ model makes teachers better understand the classroom conditions by relating the material to the experiences of students so that it can improve students' science.

Furthermore, to prove the effect of learning on students' science process skills, a hypothetical test was conducted. Hypothesis testing uses a paired Ttest with the prerequisite test for normality and homogeneity.

The pretest and posttest data normality test used the Kolmogorov Smirnov test to determine whether the scores obtained from the Learning Cycle 5E class and the Conventional classes were normally distributed.

Table 7. Pretest and Posttest Normality Test

\begin{tabular}{llrcc}
\hline & & \multicolumn{3}{c}{ Kolmogorov-Smirnov } \\
\cline { 2 - 5 } & Class & Statistic & Df & \multicolumn{1}{c}{ Sig. } \\
\hline Pretest & Learning Cycle 5E & 0,137 & 34 & 0.107 \\
& Conventional & 0,150 & 34 & 0,051 \\
Posttest & Learning Cycle 5E & 0,143 & 34 & 0,074 \\
& Conventional & 0,149 & 34 & 0,054 \\
\hline
\end{tabular}

Table 7 shows the significant value of the normality test results of the pretest and posttest in the Learning Cycle 5E class, and the conventional class is greater than the 0.05 level. From the Kolmogorov-Smirnov test results, it can be concluded that the pretest and posttest scores in both classes are normally distributed.

\begin{tabular}{lrrrl}
\multicolumn{5}{c}{ Table 8. Homogeneity Test } \\
\hline & Levine Statistic & df1 & df2 & Sig. \\
\hline Pretest & 0,206 & 1 & 66 & 0,651 \\
Posttest & 0,076 & 1 & 66 & 0,784 \\
\hline
\end{tabular}

Table 8 shows that the significance value of the homogeneity test is greater than 0.05 . The test results can be interpreted that the pretest and posttest scores in the two classes are homogeneous. Paired sample t-test with testing criteria, namely if the sig. (2-tailed) $>0.05$, then $\mathrm{H} 0$ is accepted, and $\mathrm{H} 1$ is rejected; or if the Sig. (2-tailed) value $<0.05$, then $\mathrm{H} 0$ is rejected, and $\mathrm{H} 1$ is accepted.

Table 9. Paired Sample T-Test

\begin{tabular}{llllll}
\hline & Mean & S.D. & t value & Df & $\begin{array}{l}\text { Sig. } \\
\text { (2-tailed) }\end{array}$ \\
\hline pretest & -32.397 & 10.162 & -26.290 & 67 & 0.000 \\
- & & & & & \\
postest & & & & & \\
\hline
\end{tabular}

Table 9 shows the Sig. (2-tailed) value of $0.000<0.05$, so that $\mathrm{H} 0$ is rejected, and $\mathrm{H} 1$ is accepted. It can be interpreted that the Learning Cycle 5E model affects the science process skills of students on the concept of global warming. It means that the learning cycle $5 \mathrm{E}$ encourage students to promote their ability. This learning process is in line with the core of science education with promoting scientific process in finding concepts. However, teachers must hard work in building a learning atmosphere and students can focus on developing science process skills.

Analysis of response data by calculating the respondents' scores on structured statements to determine what students think about learning the Learning Cycle model 5E (Table 10).

Table 10. Perspective of respondents

\begin{tabular}{|c|c|c|c|c|}
\hline \multirow{2}{*}{ Item } & \multirow{2}{*}{ Type of Item } & \multicolumn{2}{|c|}{ Response (\%) } & \multirow{2}{*}{ Category } \\
\hline & & Yes & No & \\
\hline Item 1 & + & 100 & 0 & Very good \\
\hline Item 2 & + & 70,6 & 0 & Good \\
\hline Item 3 & + & 100 & 0 & Very good \\
\hline Item 4 & + & 100 & 0 & Very good \\
\hline Item 5 & + & 97,1 & 2,9 & Very good \\
\hline Item 6 & + & 97,1 & 2,9 & Very good \\
\hline Item 7 & + & 97,1 & 2,9 & Very good \\
\hline Item 8 & + & 97,1 & 2,9 & Very good \\
\hline Item 9 & + & 94,1 & 5,9 & Very good \\
\hline Item 10 & + & 94,1 & 5,9 & Very good \\
\hline Item 11 & + & 100 & 0 & Very good \\
\hline Item 12 & + & 88,2 & 11,8 & Very good \\
\hline Item 13 & + & 100 & 0 & Very good \\
\hline Item 14 & + & 94,1 & 5,9 & Very good \\
\hline Item 15 & + & 100 & 0 & good \\
\hline
\end{tabular}

Based on Table 10 of the 15 question items, there were 14 question items in the very good category, while 1 question item was in a good category. The student responses show that the 
Learning Cycle 5E model can be used. As the opinion of Bilgin et al. (2013) that the Learning Cycle 5E has advantages, including increasing the interest of students in learning, motivating students, making students build their knowledge, influencing the level of understanding of students, making students responsible and participating actively in education, making learning be fun for students, and improve learning achievement. This shows that the Learning Cycle 5E model can help students according to students' responses to the Learning Cycle 5E model, which is positive.

\section{Conclusion}

The research conclusions, namely (1) Learning Cycle 5E learning model, effectively increase the value of students' science process skills. (2) positive student response to the Learning Cycle 5E model. The Learning Cycle 5E helps students acquire knowledge, understand the content, and apply science concepts and processes to authentic situations. Suggestions that can be formulated in this research, practicum using the science process skills approach, can be used as an alternative to be applied. Research instruments should be developed to be more varied; the aspects of science process skills for each indicator are made more detailed so that the emergence of science process skills is better.

\section{Reference}

Acisli, S. (2011). Effect of the Learning Model on Students' academic achievements in movement and force issues. Procedia Social and Behavioral Sciences. Vol.15(2011): 2459-2462.

Akar. (2005). Effectiveness of Learning Cycle Model on Students Understanding of AcidBase Concepts. (Unpublished Thesis). Middle East Technical University.

Arifin, Z 1. (2013). Evaluasi Pembelajaran: Prinsip, Teknik, Prosedur. Bandung: Remaja Rosdakarya.

Arini, W. (2016). Efektivitas Pembelajaran Konstekstual Praktium Mata Pelajaran Web Sisw Kelas X SMK Muhammadiyah 1 Bantul. Yogyakarta: Universitas Negeri Yogyakarta

Bilgin et al. (2013). The Effect of 5E Learning Cycle on Mental Ability of Elementary
Students. Journal of Baltic Science Education. Vol.12(5): 592-607

Depdiknas. (2008). Kurikulum Tingkat Satuan Pendidikan. Jakarta: Dikmeum. Depdiknas.

Gusdiantini, L., et al. (2017). Pengembangan Keterampilan Proses Sains Siswa Kelas V Pada Materi Gaya Gesek Melalui Pembelajaran Kontekstual. Jurnal Pena Ilmiah. Vol.2, No.1.

Kaplan, R. M. \& Saccuzo, D. P. (1993). Reabilitas dan Validitas. Edisi 3. Terjemahan: Handoko. Pustaka Pelajar, Yogyakarta.

Kulsum, U., \& Hindarto, N. (2011). Penerapan Model Learning Cycle pada Sub Pokok Bahasan Kalor untuk Meningkatkan Keaktifan dan Hasil Belajar Siswa Kelas VII SMP.Jurnal Pendidikan Fisika Indonesia Vol.2, No.128-133.

Hayati, M, Kasmadi I., \& Siti S.M (2014). Pengembangan Pembelajaran IPA SMK dengan Model Kontekstual Berbasis Proyek. Innovative Journal of Educational Technology Vol.2, Issue 1.

Laela, N., et al. (2016). Penerapan Pendekatan Contextual Teaching And Learning Untuk Meningkatkan Hasil Belajar Siswa Pada Materi Energi Panas. Pena Ilmiah Vol.1 Issu 1, No.501-510.

Permendikbud No.65 tahun 2013 tentang Standar Proses Pendidikan Dasar dan Menengah Vol.2011.

Qarareh, A. O. (2012). The effect of Using the Learning Cycle 5E Method in Teaching Science on the Educational Achievement of the Sixth Grader. International Journal of Education and Science. Vol.4(2): 123-132.

Sudjana, N. (2011). Penilaian Hasil dan Proses Belajar Mengajar. Bandung: Rosda Karya.

Surna, I. N. \& Pandeirot, O. D. (2014). Psikologi Pendidikan 1. Jakarta: Erlangga.

Usmiatin, E. (2014). Pengaruh Model Pembelajaran Inkuiri Terbimbing dan Learning Cycle 5E terhadap Prestasi Belajar IPA ditinjau dari Pengetahuan Awal. (Tesis tidak diterbitkan). Pascasarjana Universitas Negeri Malang. 
Yuniarsih, Arfiani, Hayati

Yusuf, M \& Ana. R. W. (2015). Penerapan Model Pembelajaran Discovery Learning Menggunakan Pembelajaran Tipe Shared dan Weebed untuk Meningkatkan Keterampilan Prpses Sains Vol.1, No.19-26 